\title{
School Closure and Educational Attainment:
Evidence from a Market-based
System Educational Attainment:
Evidence from a Market-based
System Educational Attainment:
Evidence from a Market-based
System
}

Autores:

Nicolas Grau

Daniel Hojman

Alejandra Mizala 


\title{
School Closure and Educational Attainment: Evidence from a Market-based System
}

\author{
Nicolas Grau* \\ Daniel Hojman* \\ Alejandra Mizala ${ }^{\dagger}$
}

February, 2017

\begin{abstract}
This paper studies the effect of school closure in the Chilean market-oriented educational system. Between 2000 and 2012 the system exhibited a large turnover: 1,651 schools closed -roughly one-sixth of the current stock- and 3,029 new schools entered, mostly private-voucher schools. We use a large panel of administrative data, which contains individual students' academic achievement and socio-demographic characteristics, to estimate some of the potential educational costs of this dynamics. We identify a causal effect of school closures on school dropouts and grade retention. School closure increases the probability of high-school dropout between 46 and 62 percent (1.7 and 2.3 percentage points). Also, school exit implies a 78 percent increase in the probability of grade retention in fifth grade. If we only consider those students that switch school at the end of the 4th grade we find an increase between 4.8 and 4.9 percentage points in grade retention.
\end{abstract}

Keywords. school choice, school closure, market turnout, education, grade retention, dropout.

JEL Classification: H4; I2.

We thank the Chilean Ministry of Education for providing the data. We are grateful to Roberto Alvarez, Diego Amador, Serafima Chirkova, Francisco Gallego, Jesse Shapiro, Miguel Urquiola, and seminar participants at the Sixth International Workshop on Applied Economics of Education, 11th World Congress of the Econometric Society and others for helpful comments and suggestions. Nicolas Grau and Daniel Hojman thank the Centre for Social Conflict and Cohesion Studies (CONICYT/FONDAP/15130009) for financial support. Alejandra Mizala acknowledges financial support from PIA-CONICYT (Basal Project FB0003). We are grateful to Cristian Labra who contributed in the early stages of this project. Emilia Brito and Alvaro Miranda provided outstanding research assistance for this project.

\footnotetext{
*Department of Economics, University of Chile and Centre for Social Conflict and Cohesion Studies (COES). E-mails: ngrau@fen.uchile.cl and dhojman@fen.uchile.cl.

${ }^{\dagger}$ Center of Applied Economics, Department of Industrial Engineering, University of Chile and CIAE. Email: amizala@dii.uchile.cl.
} 


\section{Introduction}

It is common to postulate that free-entry is central -even indispensable- for a market to work well. It is argued that "creative destruction" (Schumpeter, 1942) could lead both to vertical innovations (e.g. quality and productivity improvements) and horizontal innovations (e.g. product variety). In theory, free entry and exit may allow an industry to cleanse, leading low-quality providers to exit the market and offering more alternatives for consumers. In education, the potential benefits of creative destruction should translate into better school quality and a greater variety of educational projects available to parents. Nonetheless, a more skeptical view emphasizes the costs and disruption that could be associated to creative destruction. This might be especially complex in markets with significant failures such as information asymmetries and incomplete contracts, or if the costs of entry and exit are important (e.g. large infrastructure costs). In education, "school destruction" is associated with a disruption of children's learning and socialization process. It may also affect the live of families and involved communities. ${ }^{1}$

This paper estimates the impact of school closure in Chile, where a nationwide school voucher program was introduced in 1981, creating a dynamic educational market with high turnover rates. Specifically, for the period 2002-2012 we attempt to identify the causal effect of school closure on grade repetition and high-school dropout rates.

The Chilean case is interesting for several reasons; first, the country has a very liberalized school market that has been in place for more than 30 years without relevant changes until 2015. Second, we have new data on school exit, and use individual administrative panel data that allows us to control for individual students' characteristics. Third, recent evidence has shown that programmed school closure has potentially important pedagogic and social costs (Engberg et al 2012; de la Torre and Gwynne 2009; Kirshner et al 2009). In our case, since closures are unanticipated, the costs of adaptation are potentially larger as parents may not be prepared for the change, and the choice of a new school could be more constrained since schools tend to have fewer slots in grades different from the entry points into most schools (pre-K, first grade and ninth grade). Fourth, in the last decade many districts in the

\footnotetext{
${ }^{1}$ Recent studies focus on the impact a school closure can have in neighborhood social cohesion (Witten et al, 2001) and the development of local society (Egelund and Laustsen, 2006).
} 
United States have decided to close schools due to declining enrollment, competition from charter schools, or chronically low levels of academic performance. Other education systems, including Western Ontario or Norway have implemented similar policies in recent years. However, there is scant research on the effect school closures have on student outcomes. ${ }^{2}$

Between 1994 and 2012, the total number of schools in the system increased from 9,800 to 12,000 . The net increase in schools seems to be significantly driven by demographics and increase in coverage. However, it hides an impressive turnover. Indeed, between 2000 and 2012, 1,651 primary and secondary schools exit the market and 3,029 entered. The annual "destruction rate" for public schools and private-voucher schools was around 1.1 percent per year. Larger turnover rates seem to be associated to neighborhoods that experienced population changes during this period. School creation during the period was mainly an urban phenomenon driven by private-voucher schools in areas of urban expansion.

The main finding of the paper is the identification of large causal effects of school closure on high-school dropout rates and on grade repetition in primary school.

There is potential bias associated to selection issues in the case of high school dropouts. Students attending schools that will eventually close (treated students) may differ systematically in observable and non-observable characteristics from the rest of the students (nontreated). Also staying at a school in its final year of operation, as opposed to switching schools prior to school closure, is a second level of selection.

To deal with this potential bias we use a stringent matching design. First, we restrict the sample to students who attended schools that closed between 2005 and 2012. Second, we match students in a given school and grade who attended the school during its final year of operation with students who attended the same school and grade the year prior to closure. In addition to school and grade, the matching uses all the covariates directly available from the MoE's administrative individual database: school attendance, GPA and age. That is, our matching strategy compares the outcomes of students with similar covariates in the exact same school and grade in cohorts separated by one year -the year prior to school closure and the final year of operation. This comparison is done for all high school grades, 9 through 11 .

\footnotetext{
${ }^{2}$ Nonetheless, there is a related literature on the effects of student mobility that consistently finds adverse effects of mobility on student outcomes (Hanushek et al. 2004, Booker et al. 2007, Xu et al. 2009, Ozek 2009). Moreover, Hanushek et al 2004 also find that school mobility involves a negative externality, reducing achievement of all students in the receiving schools.
} 
Finally, to account for aggregate time-varying factors that could directly affect the dropout decision we combine matching and regression methods. We find that the effect of school closures on high-school dropout rates is statistically significant, the probability of dropping out increase in a range of 46 to 62 percent (between 1.7 and 2.3 percentage points). This effect is heterogeneous across grades, higher for grades 9th and 11th than for 10th grade.

Since grade retention depends on school-specific difficulty and grading standards, identifying the impact of school closure on retention requires us to assess the performance of students "treated" by school closure relative to their classmates in the receiving school. We take advantage of the rich database associated with the standardized test applied every year to fourth grade students, that allows us to control for characteristics of the schools, and we focus on school retention in fifth grade. To identify the impact of school closure on grade retention the year immediately after, we propose an instrumental variable approach, where the instrument is based on exogenous fluctuations of the population in schooling age in the school geographic area, this fluctuation affect school closure via enrolment shocks and do not directly affect grade retention the following year at a different school. We find a positive and statistically significant impact of school closure on grade retention, school exit implies a 78 percent increase in the probability of grade retention. If we only consider those students that switch school at the end of the 4th grade we find an increase between 4.8 and 4.9 percentage points in grade retention.

This paper contributes to a recent literature on the impact of student displacement on academic achievement. These studies have focused on the United States, and find that transition to a new school can have adverse effects on attendance and achievement gains for students from closed schools; effects that can be offset only when students move to higherperforming schools. De la Torre and Gwynne (2009) compare the learning trajectories (as measured by math and reading test scores) of students ages eight and older who were displaced by school closing in Chicago, to those of a group of students in similar schools that did not close. The authors find a negative effect on student achievement in the year the closings were announced, but find no effects after students enrolled in their new schools. The learning outcomes of displaced students depend on the characteristics of receiving schools. ${ }^{3}$ The latter

\footnotetext{
${ }^{3}$ A second Chicago study by SRI International, examined the Renaissance 2010 initiative which had the goal of closing 60-70 schools and opening 100 new smaller schools by 2010 . This study uses a matching
} 
is consistent with our results as we find that grade repetition of displaced students increases with school difficulty.

Engberg et al (2012), adds to this literature addressing the non-random sorting of student out of closed schools into new schools, and examining a school closure plan in a mid-sized urban district, that explicitly sough to move students from low value-added schools, which would be closed, to high value-added schools. They analyse the rate of absences and students' academic performance after the reassignment. They find that the transition to new schools can have an adverse effect on attendance and achievement for students from closed schools, but these effects can be minimized when students move to higher-performing schools.

These papers do not study the impact of closures on grade repetition and dropout, and focus on programmed closures in the U.S. However, their results are broadly consistent with our findings as we also find negative effects of closures on academic achievement. Although direct comparisons are not possible, the magnitude of the effects we find are considerably larger in percentual terms, something that could be partially due to the unanticipated nature of school closures in Chile. The richness and size of our individual panel allows us to control for student's cognitive skills, previous academic performance and fixed school effects.

The rest of the paper proceeds as follows. Section 2 briefly describes the Chilean school system. Section 3 describes the data, and presents some stylized facts of market exit that motivate our empirical strategy in section 4. Section 5 presents our findings on the impact of school closure on high-school dropouts and grade repetition. Section 6 concludes.

\section{Chile's School System}

In 1981, Chile introduced school finance reforms creating a liberalized school market. Three types of schools emerged: (i) Public or municipal schools are run by 345 municipalities which receive a per-student subsidy from the central government. (ii) Private-voucher schools; these are independent religious or secular institutions that receive the same per student subsidy as public schools. (iii) Private unsubsidized schools are also independent, but receive no public

strategy to examine two cohorts of students from closed schools attending 23 newly created schools and finds that students generally performed at the same levels as matched comparison students (Young et al 2009). Yet, a case study of a high school that closed in a western city shows that transferring students to new schools disrupted their relationship with teachers (Kirshner et al, 2009). 
funding. ${ }^{4}$

In 2000, private institutions accounted for 41 percent of all schools and 45.5 percent of total enrollment. Private voucher schools alone accounted for 31 percent of all schools and 36.5 percent of enrollment. In 2012 private institutions accounted for 55.2 percent of all schools and 60.5 percent of enrollment, while the participation of private voucher schools reached 49.7 percent of all schools and 53.2 percent of enrollment.

The Chilean school system has been, by design, one the most market-based in the world. Private-voucher schools are funded on a per-student formula, unlike public schools they can select they students, and can be explicitly for profit. ${ }^{5}$ Some are run by privately or publiclyheld corporations that control chains of schools, but the modal one is owned and managed by a principal/entrepreneur. While initially private-voucher schools were not allowed to charge tuition to supplement the voucher subsidy ("add-on" fees), this restriction was eased in 1993. Public schools are allowed to charge fees only at the secondary level, although in practice few of them do. Price-discrimination of families in the same school is a common practice and selection based on family characteristics and academic performance was widespread during this period. ${ }^{6}$

Until the 2015 reform there were few barriers to entry. The creation of new schools was weakly regulated and any entrepreneur willing to create a new school can do so, making it a free-entry-and-exit market.

\section{Data and Basic Statistics}

We start with a description of our measure of exit and the data used. To identify individual school exits, our starting point is the official listing of schools (Base Directorios) published annually by the Ministry of Education (MoE). It contains all schools since 1992. In principle, each school is uniquely identified by an ID (labeled $R B D$ ). For each school, the listing contains the school name, address, municipality where it is located and whether it is located in a rural area. In contrast to other systems, private schools are not required to inform their closure to

\footnotetext{
${ }^{4}$ More details about Chilean educational system can be found in Gauri (1998) and in Lara et. al. (2011).

${ }^{5}$ In 2012, nearly one third of total enrollment attended schools that were for profit.

${ }^{6}$ Structural reforms have been approved in January 2015 by the Chilean parliament. After a transition period, these reforms will imply that private-voucher schools will not be allowed to charge tuition, to be for profit, and to select students.
} 
the MoE, hence, the official registry of closures is incomplete. Additionally, some non-voucher schools have become voucher schools over time. Each of these changes could be associated with ID changes that might mistakenly be considered as an exit or entry. To properly identify exits and entries, we conducted a procedure in three stages. In the first stage, the changes in the listings yield a set of potential entries and exits. In the second stage, first-stage exit candidate is validated using an Official Exit Record of the MoE that contains all the schools that were registered as closed by local officers. In the third stage, we use the individual panel with official administrative data available for each student since the year 2002 to filter candidates of the previous stages by tracking groups of students in closing and new schools.

In addition to the sources of information described above we use other data sources. Specifically, we consider: (1) The SIMCEs: standardized test taken every year by all students in the 4 th and every other year by all 10th grade students. This database is critical to identify the effect of school closures on grade retention and high school dropouts. Moreover, from parent surveys that are carried out during the SIMCE process we obtain more information about individual students, for instance their mother's and father's education, and their opinion about schools' characteristics. (2) The administrative panel data from 2002 to 2013 for all students in the country from the Ministry of Education. This panel includes the school attended every year, the grade (and whether they repeat the grade), the attendance rate, and some basic demographic information. Our strategy is based on these individual observations, so we focus on the impact of school closures after 2002. (3) Other variables to characterize the social, demographic and economic characteristics of each municipality such as municipal population, income and unemployment rates.

Next, we present some basic stylized facts of school entry and exit dynamics in the Chilean market-oriented school system to motivate our empirical strategy. Figure 1 summarizes the basic facts of school entry and exit in Chile. Between 2000 and 2012, the number of schools that closed was 1,651, yielding an average annual exit of 127 schools per year and annual destruction rate of 1.16 per cent. Over time, the number of school closures does not seem to be slowing down, that is, school turnover is a characteristic of Chilean market-oriented system decades after the voucher-system was introduced in $1981 .^{7}$ The number of new schools that

\footnotetext{
${ }^{7}$ If we consider primary and secondary schools only, during the span 1994-2012 the average number of closures was 113 schools per year.
} 
entered the system during this period was 3,029, with an annual average of 233 schools, and a creation rate of 2.1 per cent. A more detailed analysis of the system entry and exit patterns can be found in the working paper version of this study. ${ }^{8}$ For interpretation purposes, the turnover rate of the Chilean school systems in fact quite similar to the average turnover rates found historically for middle and small-sized-firms industries (Grilliches and Regev 1979; Bartelsman, Haltiwanger, Scarpetta 2004). Perhaps a more sensible benchmark would be to compare with other educational systems but there are no systematic statistics and the causes of school closures could be quite different across countries. Still, a handful of examples are consistent with the view that the Chilean school closure rates are relatively high. ${ }^{9}$

Figure 1: Annual Exit by Type of Administration (Primary and Secondary)

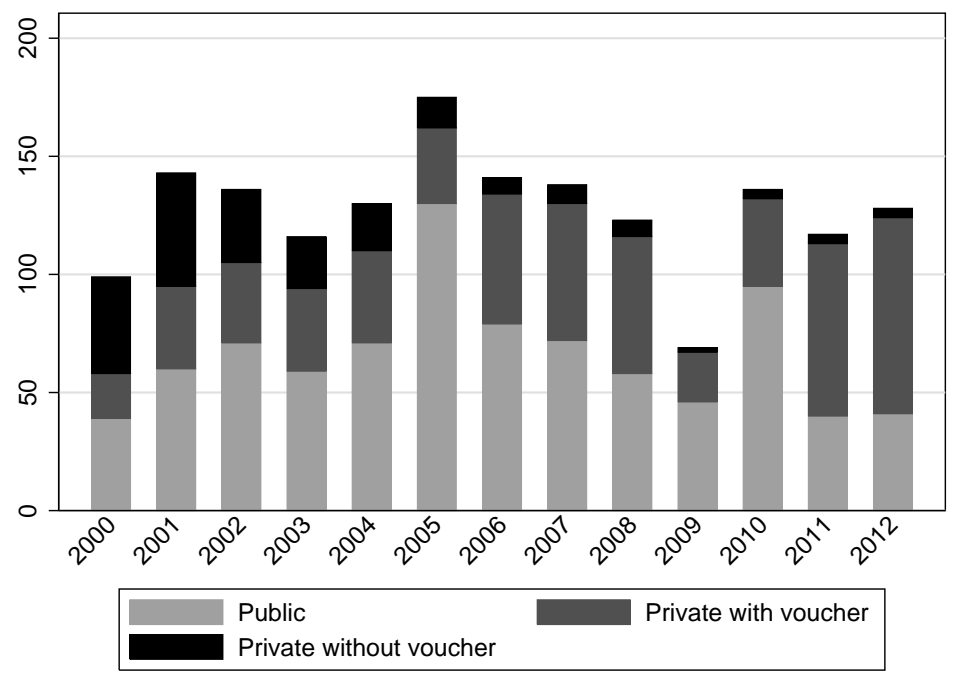

We highlight some facts regarding the school exit dynamics in Chile between 2000 and 2012 relevant to our empirical strategy presented shortly. Schools that closed during this period had an average enrollment (the year prior to exit) of about 80 students. This number is markedly smaller than the average enrollment of 300 students for schools that did not close

\footnotetext{
${ }^{8}$ Grau et al. (2015).

${ }^{9}$ Cases exhibiting similar rates of school closure to Chile have generated major public debates. In Ontario, between 1999 and 2004, 275 schools were closed prompting the community to mobilize. This number corresponds to a rate of destruction of 1.14 percent, roughly the same as in Chile between 1994 and 2012 . In the United States, the large number of closures during the last decade has led to public outcry in cities like New York, Chicago, and others. The destruction rate in the United States during this high turnover period (1995-2011) is also similar to Chile. In Denmark, with one-third of the Chilean population, the closure of 10 to 15 schools per year between 1990 and 1999, most of them rural, was also controversial (Egelund and Laustsen 2006).
} 
during this period. This fact is not particularly surprising as most schools need a critical mass to be economically viable given the considerable fixed costs of school provision. In systems with regulated entry and exit, enrollment is a common factor education administrators take into account when closing or merging schools. As mentioned, school financing in Chile is largely based on a voucher system, so that the resources for each school increase almost linearly with enrollment, schools unable to enroll a critical mass of students are not viable.

Furthermore, as Table 1 shows, relative to schools that did not close, schools that closed during this period had lower average standardized test scores, parents who were lees educated and with lower income. The normalized difference in standardized test scores are over 0.5; parents' education and income differences are also substantive.

Table 1: Differences Between schools Closing And Not Closing

\begin{tabular}{lcccccc}
\hline \hline & \multicolumn{5}{c}{ 4th Grade Information } \\
\cline { 2 - 6 } & \multicolumn{2}{c}{ Test Scores } & \multicolumn{2}{c}{ Years of Education } & Income & Number of \\
& Lenguage & Math & Mother & Father & & Schools \\
\hline \multirow{2}{*}{$\begin{array}{l}\text { Schools not closing in the period } \\
\text { Schools closing in the period }\end{array}$} & -0.03 & -0.04 & -0.07 & -0.07 & -0.03 & 8701 \\
Normalized differences & -0.50 & -0.51 & -0.37 & -0.35 & -0.21 & 283 \\
& 0.51 & 0.52 & 0.30 & 0.28 & 0.22 & \\
& & & 10 th Grade Information & \\
\cline { 2 - 7 } & & & & & & \\
Schools not closing in the period & 0.01 & 0.01 & 0.01 & 0.01 & 0.01 & 2921 \\
Schools closing in the period & -0.65 & -0.61 & -0.20 & -0.13 & -0.09 & 162 \\
Normalized differences & 0.72 & 0.68 & 0.20 & 0.13 & 0.09 & \\
\hline
\end{tabular}

Note: To calculate the statistics about 4th grade, we use the database considered to estimate the effect of school closure on grade retention in 5th grade. This database considers the period 2005-2011. To calculate the statistics about 10th grade, we use the database considered to estimate the effect of school closure on dropout in high-school. This database includes from 2002 to 2012.

Figure 2 illustrates two additional facts about closing schools. First, on average, these schools show declining enrollment. Second, the composition of students that stay at school the closing year arrives does not appear to be random. To see this, we use GPA information to define a proxy measure of cognitive skills. In particular, if the school $j$ closed in year $t$, we calculate the standardized GPA of the students in that school in year $t-4$. Then, the average cognitive skills of the students in that school in year $t-t^{\prime}\left(t^{\prime} \in\{0,1,2,3,4\}\right)$ is the standardized GPA, calculated in year $t-4$ of the students who are still attending that school in year $t-t^{\prime}$. The average cognitive skills of students who remain at the school decline 
as the school approaches to its closure. The facts show that schools that close are smaller and with students coming from lower socioeconomics families. Also, their dynamic of losing students show that the ones with best academic performance leave first. All these facts must be accounted for when estimating the impact of school closure on students' outcomes.

Figure 2: SchOOL SIZE AND STUdENTS CHARACTERISTICS

APPROACHING THE CLOSURE

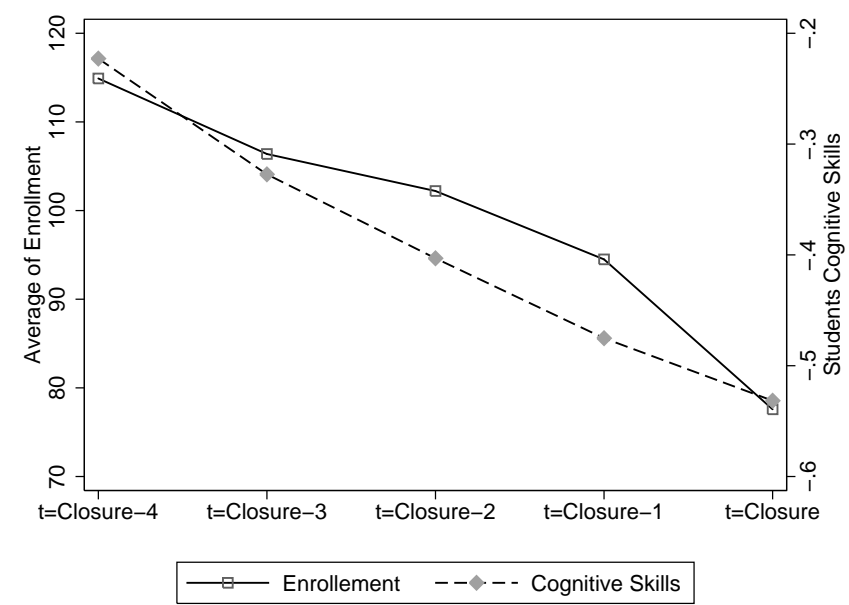

Note: The average students cognitive skills of a school that is closing in $t$ more years is defined in two steps. First, we calculate a standardized GPA of each student using her GPA and the GPA distribution of her school, four years before the closure. Second, the average student cognitive skill at time Closure $-t$, where $t \in\{1,2,3,4\}$, is calculated as the standardized GPA average of all students who are attending schools which are closing in $t$ years.

\section{Empirical Strategy}

We are interested in assessing the impact of school closure on two educational outcomes, dropping out of high school and grade retention in primary school. ${ }^{10}$ The basic identification problem is selection: the students "treated" by school closure could be systematically different to those attending schools that do not close. Given the different nature of the data available and the comparisons required to identify an effect in each case, we develop a separate empirical strategy for each outcome of interest. Specifically, since grade retention depends on schoolspecific difficulty and grading standards, identifying the impact of school closure on retention

\footnotetext{
${ }^{10}$ Both are related. In fact, there is solid evidence that grade repetition causes student dropout, see for instance Diaz et. al. (2016); Jacob and Lefgren (2009); and Manacorda, M. (2012).
} 
requires us to asses the performance of students "treated" by school closure relative to their classmates in the receiving school. In contrast, potential dropouts leave the system after school closure. In this case it seems natural to compare the outcomes of those students enrolled at a closing school in its final year of operation (treated) with those of students in the preceding cohort -one year prior to school closure- at the same school (control).

\subsection{High-School Dropouts}

The potential bias associated to selection issues in the case of high-school dropouts is addressed using a stringent matching design. We can think of two levels of selection. First, as seen earlier, students attending schools that will eventually close differ systematically in observable characteristics from the rest of the students (Table 1). They have lower test scores and their parents are less educated. At the same time, as illustrated by Figure 1, on average, schools that close have a declining enrolment over time and this attrition is not random: better students in terms of academic performance have higher probability of leaving those schools. Hence, staying at a school in its final year of operation (as opposed to switching prior to school closure) is a second level of selection.

To deal with the first level of selection we restrict the sample to students who attended schools that closed between 2005 and 2012. The second level of selection is addressed by matching students in a given school and grade who attended a school during its final year of operation with students with similar observable characteristics who attended the same school and grade in the previous cohort -i.e. the year prior to closure. That is, our matching strategy compares the outcomes of students with similar covariates in the exact same school and grade in cohorts separated by one year -the year prior to school closure and the final year of operation. This comparison is done for all high-school grades, 9th through 11th. In addition to school and grade, the matching uses all the covariates available from the MoE's administrative individual database: school attendance, GPA and age. ${ }^{11}$ These variables are used to compute the nearest-neighbour matches for the Mahalanobis metric. The students' school and grade are discrete covariates, thus, the matching is exact in these variables.

We define $t$ some year between 2005 and 2012. We say that a student drops out at time

\footnotetext{
${ }^{11}$ The variables associated with the SIMCE test dataset - students' test scores and sociodemographic characteristics- are not available for all high-school students because the SIMCE test was not given to secondary students in a yearly basis during the 2005-2012 period
} 
$t$ if he or she was enrolled in year $t-1$ and did not enrol in year $t$. Let $Y_{i, t}$ be a binary variable taking the value 1 if student $i$ drops out at time $t$ and 0 , otherwise. Let $W_{i, t}$ denote the treatment variable, that is, $W_{i, t}=1$ if student $i$ 's school closed a time $t-1$ and $W_{i, t}=0$, otherwise. That is, we identify the treatment with the fact that the student attended a school in its final year of operation and therefore, is forced to find a different school if he/she aims to continue studying. Using the potential outcomes approach introduced Rubin (1974), let $Y_{i, t}(w)$ denote the potential outcome of student $i$ at time $t$, where $w=1$ if $i$ 's school closes at time $t-1$ and $w=0$ if it stays open. The average treatment effect on the treated (ATT) is defined as $\tau^{A T T}=E\left[Y_{i, t}(1)-Y_{i, t}(0) \mid W_{i, t}=1\right]$ while the average treatment effect in the population of students in schools that eventually closed (ATE) is $\tau^{A T E}=E\left[Y_{i, t}(1)-Y_{i, t}(0)\right]$.

For those treated by school closure we observe only $Y_{i, t}(1)=Y_{i, t}$ and we impute $Y_{i, t}(0)$ using the matching procedure. For each $i$ treated $\left(W_{i, t}=1\right)$, we assign the set of matches $J_{M}(i)$ corresponding to the $M$ nearest-neighbors in the untreated group $\left(W_{i, t}=0\right)$ using the Mahalanobis metric. If $g(i, t)$ is student $i$ 's grade at time $t$ and $s(i, t)$ is her school, $J_{M}(i)$ is a subset of $J^{-}=\{j / g(j, t-2)=g(i, t-1)$ and $s(j, t-2)=s(i, t-1)\}$. In the results section we report estimates for $M=1$ (single-case match) and $M=3$. The imputed value for $Y_{i, t}(0)$, denoted by $\hat{Y}_{i, t}(0)$, is the average outcome of those individuals in the set of matches, that is, $\hat{Y}_{i, t}(0)=\frac{1}{M} \sum_{j \in J_{M}(i)} Y_{j, t}$. Using this we can estimate the ATT as the average difference $Y_{i, t}(1)-Y_{i, t}(0)$ across treated individuals, that is,

$$
\hat{\tau}^{A T T}=\frac{1}{N_{1}} \sum_{i, t: W_{i, t}=1} Y_{i, t}(1)-\hat{Y}_{i, t}(0),
$$

where $N_{1}=\sum_{i, t: W_{i, t}=1} 1$, is the total number of treated individuals.

Similarly, we can also assign to each untreated individual $i\left(W_{i, t}=0\right)$ the set of $M$ nearest-neighbors in the treated group $J_{M}(i)$. In this case, we observe $Y_{i, t}(0)=Y_{i, t}$ and impute $\hat{Y}_{i, t}(1)=\frac{1}{M} \sum_{j \in J_{M}(i)} Y_{j, t}$. An estimate of the ATE

$$
\hat{\tau}^{A T E}=\frac{1}{N_{1}} \sum_{i, t: W_{i, t}=1} Y_{i, t}(1)-\hat{Y}_{i, t}(0)+\frac{1}{N_{0}} \sum_{i, t: W_{i, t}=0} \hat{Y}_{i, t}(1)-Y_{i, t}(0),
$$

where $N_{0}=\sum_{i, t: W_{i, t}=0} 1$, is the total number of non-treated individuals. 
The approach we use to identify the treatment effect relies on the usual assumptions used in matching (Imbens 2004; Imbens and Wooldridge 2009). Namely, the unconfoundedness and overlap assumptions. Intuitively, unconfoundedness means that students in consecutive cohorts at the same school with similar observables either do not differ considerably on unobservables or, conditional on observables, these unobservables do not explain whether they remain or not in that school in its final year of operation. ${ }^{12}$

If our treated and non-treated students were observed at the same point in time the previous assumptions are sufficient for an unbiased estimate of the treatment. However, our identification strategy is based on comparing the outcomes of consecutive cohorts in the same school and grade, in consecutive years. Hence, an additional assumption is needed. Namely, we require that school and aggregate factors that might directly affect the dropout decision are unchanged in two consecutive years. This assumption requires that aggregate economic conditions that affect dropouts decisions (for instance, labor market conditions) are similar in consecutive years.

However, this may not hold if these variables change considerably from one year to the next in our time window. For example, while the impact of the 2008-2009 financial crisis was limited in Chile leading to a moderate and temporary increase in unemployment in 2009, these type of fluctuations could still affect the occupational decisions of the students who are considering dropping out. To account for aggregate time-varying factors that could directly affect the dropout decision we combine matching and regression methods. Specifically, we introduce as an additional covariate a time-dummy for the year of closure of each student's school and use the regression correction method suggested by Abadie and Imbens (2011).

However, this strategy, even after controlling for year-fixed effects, does not account for year-effects nor school-level changes in the last year of operation, that could directly affect the dropout decision. If these final-year school changes are part of a typical closing process (e.g. personnel reductions) we can reinterpret this change as part of the closure treatment. To check if our findings are indeed confined to the impact of school closure we run a placebo in which the outcomes of two consecutive cohorts are compared one year before the school

\footnotetext{
${ }^{12}$ The unconfoundedness assumption is also referred as "selection on observables".
} 
closure.

\subsection{Grade retention}

In order to take advantage of the rich SIMCE database which is applied every year since 2005 and covers nearly 95 per cent of all fourth-grade students, we focus on school retention in the fifth grade. To identify the impact of school closure on grade retention the year immediately after, we propose an instrumental variables approach (IV) in the vein of the instruments introduced by Bartik (1991). ${ }^{13}$

Formally, for each student $i$ in the fifth grade at time $t$, let $X_{i, t}$ be a vector of individual characteristics at time $t$ in the fifth grade. As before, the regressor of interest is denoted $W_{i, t}$, a binary variable taking the value 1 if student $i$ 's school closes in period $t-1$ (when the student was in the fourth grade) and 0 , otherwise. As before, let $s(i, t)$ be the school of student $i$ at time $t$. To measure the impact of the binary and possibly endogenous regressor $W_{i, t}$ on the binary outcome $Y_{i, t}$ we estimate the bi-probit model (Wooldridge, 2002)

$$
\begin{gathered}
W_{i, t}=\mathbb{1}\left(\beta_{4} X_{i, t-1}+\beta_{5} Q_{s(i, t-1)}+\gamma Z_{i, t-1}+v_{i, t-1} \geq 0\right) . \\
Y_{i, t}=\mathbb{1}\left(\beta_{1} X_{i, t}+\beta_{2} Q_{s(i, t)}+\beta_{3} q_{i, s^{\prime}, t-1}+\alpha W_{i, t}+u_{i, t} \geq 0\right)
\end{gathered}
$$

Equation (1) describes the relationship between the school closure $(W)$, individual and school characteristics $(X$ and $Q)$ and an instrument $(Z)$ described shortly. Equation (2) describes the relationship between the grade retention $(Y)$ and school closure $(W)$, controlling for individual $(X)$ and school $(Q)$ characteristics. In this context, $\left(u_{i, t}, v_{i, t-1}\right)$ is independent of $X, Q, Z$, and $q$ and distributed as bivariate normal with mean zero, unit variance, and $\rho=\operatorname{Corr}\left(u_{i, t}, v_{i, t-1}\right)$. The model is estimated using MLE.

The instrument $(Z)$ we propose is an exogenous determinant of school enrolment. To motivate our choice, we point out that in the Chilean voucher system, school revenues are proportional to enrolment and, since schools have important non-variable costs (e.g. infrastructure, services) or costs that vary with the number of classrooms rather than the number of students, a minimum enrolment is required for the school to remain financially sustainable.

\footnotetext{
${ }^{13}$ For other applications of this type of instrument see Aizer (2010), Blanchard et. al. (1992), Card (2001), John Bound and Harry J. Holzer (2000), and David H. Autor and Mark G. Duggan (2003).
} 
Indeed, as shown earlier, schools that close have declining enrolment and final-year enrolment much lower than an average school. This suggests a negative correlation between school closure and enrolment. Furthermore, school enrolment is associated with parental choices and school admission policies. Since enrolment might be correlated with unobserved student characteristics captured by $u_{i, t}$, it is unlikely to satisfy the exclusion restriction. However, if a geographic area is served by many schools, local fluctuations of the population in schooling age are plausibly exogenous shocks on the enrolment of a particular school in that area. ${ }^{14}$ These demographic fluctuations affect school closure (via enrolment shocks) without directly affecting grade retention the following year at a different school. In concrete, let $N_{m, t}$ be the total population of students in municipality $m$ at time $t$ and let $m(s)$ denote the municipality of school $s$. Denote by $h_{s}$ the share of students of school $s$ during the year 2005, i.e., prior to the time window considered in our estimation. The instrument we propose is defined as

$$
Z_{i, t}=h_{s} \frac{N_{m(s), t}-N_{m(s), 2005}}{N_{m(s), 2005}}
$$

where $s=s(i, t)$. Note that the enrollment of school $s$ in 2002 is given by $h_{s} N_{m(s), 2005}$, so that, if enrollment shares in a municipality remain constant over time, $Z_{i, t}$ coincides with that school's enrollment in year $t$. Importantly, $h_{s}$ could still be endogenous to student characteristics. To account for this, the vector of school characteristics $Q$ in equation (1) includes a measure of enrollment in 2005 as a proxy of initial conditions.

It is worth mentioning that this approach will deliver unbiased estimates of $\alpha$ to the extent that the variation in the communal population does not change the student composition of the school in terms of unobservable variables. An indirect way to test this is to run two variants of the bi-probit model, one including the characteristics of each municipality and one not including these controls, and check the stability of the estimation of $\alpha$ for these different specifications.

\footnotetext{
${ }^{14}$ We observe that while school choice in Chile is not geographically restricted (i.e. children can, in principle, attend schools in distant municipalities), roughly 80 per cent of elementary school students attend a school located in the same municipality where she lives. With this in mind, we use the municipality as the relevant geographic area.
} 


\section{$5 \quad$ Results}

\subsection{High-school Dropouts}

We start by assessing the balance in covariates between treated and controls students in the pre and post matching samples. Recall that the treated correspond to students who attended a closing school in its final year of operation, while the controls are students in the preceding cohort in the same school and grade the year prior to its final operation year. Table 2 shows that normalized differences in school attendance, GPA and age between treatment and controls prior to the matching are all statistically significant but not huge. Students that stay at a closing school in its final year of operation have lower attendance, lower GPA and are slightly older than those at school the year prior to closure. Note that, since some of the latter group stays in the school when it closes as well (i.e., some controls are also treatments a year after), these differences are due to those who switch schools prior to closure. The post matching differences are non-existent in the ATE matching and very small for the ATT matching. 
Table 2: Differences in COVARIATES Among Different treatment And CONTRol GROUPS

\begin{tabular}{|c|c|c|c|c|c|}
\hline \multirow[b]{2}{*}{ Variable } & \multicolumn{5}{|c|}{ Pre Matching } \\
\hline & Closing at $\mathrm{t}$ & Closing at $t+1$ & Norm. Dif. & Statistic & $\mathrm{p}$-value \\
\hline Attendance & 90.814 & 91.651 & -0.11 & -9.843 & 0.000 \\
\hline GPA & 51.9 & 52.6 & -0.11 & -9.508 & 0.000 \\
\hline Age & 15.18 & 15.14 & 0.02 & 1.922 & 0.055 \\
\hline \multirow[t]{2}{*}{$\mathrm{N}$} & 15,102 & 16,717 & & & \\
\hline & \multicolumn{5}{|c|}{ Post Matching (ATT) } \\
\hline Variable & Closing at $\mathrm{t}$ & Closing at $t+1$ & Norm. Dif. & Statistic & $\mathrm{p}$-value \\
\hline Attendance & 92.305 & 92.689 & -0.06 & -3.870 & 0.000 \\
\hline GPA & 54.7 & 54.7 & 0.00 & 0.004 & 0.997 \\
\hline Age & 14.95 & 14.91 & 0.03 & 2.164 & 0.031 \\
\hline \multirow[t]{2}{*}{$\mathrm{N}$} & 7,881 & 7,881 & & & \\
\hline & \multicolumn{5}{|c|}{ Post Matching (ATE) } \\
\hline Variable & Closing at $\mathrm{t}$ & Closing at $t+1$ & Norm. Dif. & Statistic & $\mathrm{p}$-value \\
\hline Attendance & 92.740 & 92.791 & -0.01 & -0.773 & 0.439 \\
\hline GPA & 55.1 & 54.9 & 0.01 & 0.861 & 0.389 \\
\hline Age & 14.94 & 14.92 & 0.01 & 0.942 & 0.346 \\
\hline $\mathrm{N}$ & 16,824 & 16,824 & & & \\
\hline
\end{tabular}

Note: Norm. Dif. stands for the normalized differences in the means of the treatment (Closing at $t$ ) and control (Closing at $t+1$ ) groups.

Table 3 shows the ATT and ATE for all high-school grades in different variants of the matching estimator using mahalanobis distance. Specifically, column (1) corresponds to the estimation that for each treated individual only considers her nearest neighbour as control, column (2) considers the three nearest neighbours, and column (3) also considers the nearest neighbour but in this case we use the Abadie-Imbens regression correction including year fixed effects as covariates. ${ }^{15}$ We find a positive, significant and robust effect across specifications for the estimation whose sample contains students attending grades 8th, 10th, and 11th (the first row for ATT and ATE), the point estimate for the effect of school closure on student dropping out is between 1.7 and 2.3 percentage points. These estimates are not statistically different from each other, and there is no clear pattern across different specifications. Regarding the magnitudes, given that the dropout rate for the students in this sample is about 3.7 percent, the estimates range from an effect of 46 to 62 percent.

Table 3 also shows the estimates for each of the grades. The results are heterogeneous

\footnotetext{
${ }^{15}$ We implement this approach following Abadie et. al. (2004).
} 
across grades. For students whose schools closed when they attended 9th grade, closure increases the dropout rate between 1.4 and 2.1 percentage point, and between 3.4 and 4.3 percentage points for students treated in the 11th grade. The estimates also suggest that there is no effect for those students in the 10th grade. This heterogeneity is consistent with the differences in dropout rates across grades: the dropout rates are much higher for grades 9 th and 11th than for grade 10th, suggesting that differences in grade difficulty matter. ${ }^{16}$

Table 3: EfFect of SChool Closure on Student Dropout

\begin{tabular}{|c|c|c|c|}
\hline & \multicolumn{3}{|c|}{ Average treatment effect on the treated (ATT) } \\
\hline & $(1)$ & $(2)$ & $(3)$ \\
\hline & Nearest neighbor & 3-Nearest neighbor & Abadie-Imbens correction \\
\hline $\begin{array}{l}\text { All grades } \\
{[N=22,189]}\end{array}$ & $\begin{array}{l}0.017^{* * * *} \\
(0.0034)\end{array}$ & $\begin{array}{l}0.023^{* * * *} \\
(0.0028)\end{array}$ & $\begin{array}{l}0.020^{* * * *} \\
(0.0034)\end{array}$ \\
\hline $\begin{array}{l}9 \text { th grade } \\
{[N=8,473]}\end{array}$ & $\begin{array}{l}0.017^{* * *} \\
(0.0045)\end{array}$ & $\begin{array}{l}0.021^{* * *} \\
(0.0040)\end{array}$ & $\begin{array}{l}0.020^{* * *} \\
(0.0046)\end{array}$ \\
\hline $\begin{array}{l}\text { 10th grade } \\
{[N=7,640]}\end{array}$ & $\begin{array}{c}0.001 \\
(0.0062)\end{array}$ & $\begin{array}{l}0.009 \\
(0.0050)\end{array}$ & $\begin{array}{c}0.001 \\
(0.0062)\end{array}$ \\
\hline \multirow[t]{2}{*}{$\begin{array}{l}11 \text { th grade } \\
{[N=6,076]}\end{array}$} & $\begin{array}{l}0.034^{* * *} \\
(0.0067) \\
\end{array}$ & $\begin{array}{r}0.043^{* * *} \\
(0.0059) \\
\end{array}$ & $\begin{array}{l}0.042^{* * *} \\
(0.0068) \\
\end{array}$ \\
\hline & \multicolumn{3}{|c|}{ Average treatment effect (ATE) } \\
\hline $\begin{array}{l}\text { All grades } \\
{[N=22,189]}\end{array}$ & $\begin{array}{l}0.018^{* * *} \\
(0.0030)\end{array}$ & $\begin{array}{l}0.018^{* * *} \\
(0.0027)\end{array}$ & $\begin{array}{l}0.017^{* * * *} \\
(0.0030)\end{array}$ \\
\hline $\begin{array}{l}9 \text { th grade } \\
{[N=8,473]}\end{array}$ & $\begin{array}{l}0.015^{* * *} \\
(0.0044)\end{array}$ & $\begin{array}{l}0.014^{* * *} \\
(0.0039)\end{array}$ & $\begin{array}{l}0.015^{* * *} \\
(0.0044)\end{array}$ \\
\hline $\begin{array}{l}\text { 10th grade } \\
{[N=7,640]}\end{array}$ & $\begin{array}{l}0.007 \\
(0.0055)\end{array}$ & $\begin{array}{l}0.006 \\
(0.0047)\end{array}$ & $\begin{array}{l}0.002 \\
(0.0056)\end{array}$ \\
\hline $\begin{array}{l}11 \text { th grade } \\
{[N=6,076]}\end{array}$ & $\begin{array}{l}0.038^{* * *} \\
(0.0060)\end{array}$ & $\begin{array}{l}0.041^{* * *} \\
(0.0055)\end{array}$ & $\begin{array}{l}0.041^{* * *} \\
(0.0060)\end{array}$ \\
\hline
\end{tabular}

Note: Standard errors in parentheses; * Significant at the 10 percent level, ** Significant at the 5 percent level. *** Significant at the 1 percent level. Column (3) presents an estimation that removes the conditional bias asymptotically, making matching estimators root-N-consistent, Abadie and Imbens (2011).

As a robustness test, we conduct a placebo test. Specifically, we repeat the matching for students in the same school and grade in consecutive cohorts but one year ahead of school closure. That is, the treated are now students who attend the school one year prior to its final year of operation while the controls are the closest matches from the previous cohort. As seen in Table 4 (ATE and ATT estimates), the placebo treatment has no effect whatsoever.

\footnotetext{
${ }^{16}$ Official statistics of the Chilean Ministry of Education.
} 
This result reassures our identification strategy.

A final robustness check is to run a regression in the entire population of students as opposed to the restricted sample, that is, including students who attended schools that closed between 2005 and 2012 as well as students whose schools did not close during this period. ${ }^{17}$ Of course, as argued earlier, since students in schools that close are significantly different than the rest of the population, estimating the impact of school closure on high-school dropout in the entire population may lead to a biased estimation. Table 7 in Appendix A shows the probit estimation (its marginal effects) on the sample of students and years for which the eight-grade SIMCE database is available (this database includes numerous socio-demographic and previous educational performance controls). The estimates of this exercise for the impact of school closure on students' dropout are remarkably similar to the ATT and ATE matching estimates obtained for the restricted sample. The small differences in the estimates is probably due to the quality of the controls in the SIMCE database. In particular, when we include all the regressors, the effect of school closure on student dropout is a statistically significant increase of 0.44 percentage points. Since in this sample the dropout rate is around 1.4 percent per year, our estimate implies that school closure increases the probability of dropping out by 31 percent.

\footnotetext{
${ }^{17}$ The details of the sample and model specification are presented in Appendix A
} 
Table 4: Placebo for the EFfect of SChool Closure on Student Dropout

\begin{tabular}{|c|c|c|c|}
\hline & \multicolumn{3}{|c|}{ Average treatment effect on the treated (ATT) } \\
\hline & (1) & $(2)$ & $(3)$ \\
\hline & Nearest neighbor & 3-Nearest neighbor & Abadie-Imbens correction \\
\hline $\begin{array}{l}\text { All grades } \\
{[N=26,498]}\end{array}$ & $\begin{array}{l}-0.000 \\
(0.0031)\end{array}$ & $\begin{array}{l}0.003 \\
(0.0026)\end{array}$ & $\begin{array}{l}0.003 \\
(0.0034)\end{array}$ \\
\hline $\begin{array}{l}\text { 9th grade } \\
{[N=10,207]}\end{array}$ & $\begin{array}{l}0.001 \\
(0.0042)\end{array}$ & $\begin{array}{c}0.002 \\
(0.0038)\end{array}$ & $\begin{array}{c}0.002 \\
(0.0046)\end{array}$ \\
\hline $\begin{array}{l}\text { 10th grade } \\
{[N=8,869]}\end{array}$ & $\begin{array}{c}-0.007 \\
(0.0062)\end{array}$ & $\begin{array}{c}-0.001 \\
(0.0050)\end{array}$ & $\begin{array}{c}-0.004 \\
(0.0062)\end{array}$ \\
\hline \multirow[t]{2}{*}{$\begin{array}{l}\text { 11th grade } \\
{[N=7,422]}\end{array}$} & $\begin{array}{l}0.006 \\
(0.0057)\end{array}$ & $\begin{array}{l}0.006 \\
(0.0049) \\
\end{array}$ & $\begin{array}{c}0.013^{*} \\
(0.0068)\end{array}$ \\
\hline & \multicolumn{3}{|c|}{ Average treatment effect (ATE) } \\
\hline $\begin{array}{l}\text { All grades } \\
{[N=26,498]}\end{array}$ & $\begin{array}{c}-0.002 \\
(0.0025)\end{array}$ & $\begin{array}{c}-0.003 \\
(0.0021)\end{array}$ & $\begin{array}{c}-0.003 \\
(0.0030)\end{array}$ \\
\hline $\begin{array}{l}9 \text { th grade } \\
{[N=10,207]}\end{array}$ & $\begin{array}{c}-0.001 \\
(0.0036)\end{array}$ & $\begin{array}{c}-0.003 \\
(0.0032)\end{array}$ & $\begin{array}{c}-0.003 \\
(0.0044)\end{array}$ \\
\hline $\begin{array}{l}\text { 10th grade } \\
{[N=8,869]}\end{array}$ & $\begin{array}{c}-0.008^{*} \\
(0.0048)\end{array}$ & $\begin{array}{c}-0.006 \\
(0.0041)\end{array}$ & $\begin{array}{c}-0.008 \\
(0.0056)\end{array}$ \\
\hline $\begin{array}{l}11 \text { th grade } \\
{[N=7,422]}\end{array}$ & $\begin{array}{l}0.003 \\
(0.0045)\end{array}$ & $\begin{array}{l}0.000 \\
(0.0039)\end{array}$ & $\begin{array}{l}0.005 \\
(0.0060)\end{array}$ \\
\hline
\end{tabular}

Note: Treated is defined as a student whose school is closing in one more year, and control is defined as a students whose school is closing in two more years. Standard errors in parentheses; ${ }^{*}$ Significant at the 10 percent level, ${ }^{* *}$ Significant at the 5 percent level. *** Significant at the 1 percent level. Column (3) presents an estimation that removes the conditional bias asymptotically, making matching estimators root-N-consistent, Abadie and Imbens (2011).

\subsection{Grade retention}

The biprobit summarized by equations (1) and (2) is estimated using MLE. Table 5 shows the estimation of different variants of equation (1), confirming a negative and statistically significant relationship between school closure and our instrument of school enrolment. This positive and significant relationship is stable to different specifications, namely, considering all students as control group (columns (1) and (2)) and only considering the students who switched school for a reason different from school closure as control group (columns (3) and (4)). Furthermore, the relationship is also stable to the inclusion of municipal characteristic as covariates. ${ }^{18}$

\footnotetext{
${ }^{18}$ These are four variables: the municipal average score for the language SIMCE test, the municipal average score for the math SIMCE test, the municipal average for fathers' years of education, and the municipal
} 
The estimates of equation (2) are summarized in Table 6. We run four specifications, all of them include a large set of covariates: individual test scores, GPA, attendance, all at 4th grade; gender; the enrollment of the school in 2005; a set of dummies for parental education; dummies for previous grade retention, a set of characteristics for the schools attended at 4th and 5th grade (e.g., the average test score); Columns (3) and (6) also consider municipal characteristics. In addition, as a reference point we estimate a simple probit model of retention on school closure (without correcting for endogeneity); these results are presented in Columns (1) and (4). Columns (2), (3), (5), and (6) present the biprobit estimates. The estimates reported in columns (1)-(3) consider the sample of all students. The sample for columns (4)-(6) includes only those students who switched schools at the end of 4th grade.

In all biprobit specifications we find positive and statistically significant coefficients of school closure on grade retention. To asses the magnitude of the effects, Table 8 of Appendix B presents the marginal effects. ${ }^{19}$ Our estimates for the sample of all students, imply an increase between 2.4 and 2.8 percentage points in grade retention associated to school closure. The estimates restricted to the subsample of those students who switched schools at the end of 4th grade, imply an increase between 4.8 and 4.9 percentage points in grade retention associated to school closure. These are sizeable effects. Since the grade retention rate in the estimation sample is equal to 3.02 percent, our lowest estimated parameter represents a 78 percent increase of the retention rate due to school closure.

There are different aspects of our results worth to mention. First, the coefficients of the control variables are quite intuitive: retention decreases with attendance and with student knowledge as measured by standardized tests results in Math and Language. It also decreases with the mother's and father's education level. Second, the estimated parameter for the impact of school closure on grade retention is remarkably stable to the inclusion of municipal characteristics. This is an important result since the soundness of our instrument depends on the absence of student sorting on unobservable variables correlated with fluctuations in municipal population. Finally, Table 9 in Appendix B presents the OLS estimations for average for mothers' years of education.

${ }^{19}$ The coefficients associated to school closure are statistically significant. However, the estimated marginal effects have lower significance (coefficients significant at the 13 percent level) when we calculate the standard errors using the delta method. Still, since the latter is an approximation, the relevant estimates to make inference are the estimated parameters of equation (2) and the p-values are 0.095, for Columns (2), (3), (5), (6), respectively are $0.060,0.052$, and 0.052 . 
the effect of school closure on grade retention, including the same covariates as before and fixed effects for the 5th grade school, which we cannot include in our biprobit estimations. The estimated coefficients are in general significant and similar in magnitude to the biprobit estimates. As in the case of high-school dropout, this is no surprising given the quality of our control variables.

Table 5: Effect of School closure on grade Retention (Equation (1))

\begin{tabular}{|c|c|c|c|c|}
\hline & \multicolumn{2}{|c|}{ All Students } & \multicolumn{2}{|c|}{ Students Switching Schools } \\
\hline & Biprobit (1) & Biprobit (2) & Biprobit (1) & Biprobit (2) \\
\hline $\begin{array}{l}Z_{i t}: \text { Demographic } \\
\text { fluctation }\end{array}$ & $\begin{array}{c}-3.355^{*} \\
(1.869)\end{array}$ & $\begin{array}{c}-4.351^{* *} \\
(1.750)\end{array}$ & $\begin{array}{l}-4.681^{*} \\
(2.447)\end{array}$ & $\begin{array}{c}-6.134^{* *} \\
(2.833)\end{array}$ \\
\hline $\begin{array}{l}\text { Average math test score } \\
\text { of the School }\end{array}$ & $\begin{array}{c}0.0139^{* * *} \\
(0.00485)\end{array}$ & $\begin{array}{l}0.0120^{* *} \\
(0.00492)\end{array}$ & $\begin{array}{c}0.0177^{* * *} \\
(0.00572)\end{array}$ & $\begin{array}{l}0.0158^{* * *} \\
(0.00575)\end{array}$ \\
\hline $\begin{array}{l}\text { Average language test score } \\
\text { of the School }\end{array}$ & $\begin{array}{c}-0.0328^{* * *} \\
(0.00602)\end{array}$ & $\begin{array}{c}-0.0303^{* * *} \\
(0.00596)\end{array}$ & $\begin{array}{c}-0.0360^{* * *} \\
(0.00700)\end{array}$ & $\begin{array}{c}-0.0339^{* * *} \\
(0.00691)\end{array}$ \\
\hline $\begin{array}{l}\text { Grade retention rate } \\
\text { of the school }\end{array}$ & $\begin{array}{r}-0.0163 \\
(0.490)\end{array}$ & $\begin{array}{l}-0.175 \\
(0.490)\end{array}$ & $\begin{array}{l}-0.377 \\
(0.613)\end{array}$ & $\begin{array}{l}-0.558 \\
(0.611)\end{array}$ \\
\hline Enrollment in 2005 & $\begin{array}{c}-0.00114 * * * \\
(0.000219)\end{array}$ & $\begin{array}{c}-0.00118^{* * *} \\
(0.000228)\end{array}$ & $\begin{array}{c}-0.00119^{* * *} \\
(0.000250)\end{array}$ & $\begin{array}{c}-0.00123 * * * \\
(0.000260)\end{array}$ \\
\hline $\begin{array}{l}\text { Fraction of fathers with } \\
\text { primary education }\end{array}$ & $\begin{array}{l}-0.661 \\
(0.947)\end{array}$ & $\begin{array}{c}-0.152 \\
(1.002)\end{array}$ & $\begin{array}{l}-0.0276 \\
(1.092)\end{array}$ & $\begin{array}{c}0.483 \\
(1.130)\end{array}$ \\
\hline $\begin{array}{l}\text { Fraction of fathers with } \\
\text { incomplete secondary education }\end{array}$ & $\begin{array}{l}-1.043 \\
(0.962)\end{array}$ & $\begin{array}{l}-0.595 \\
(0.992)\end{array}$ & $\begin{array}{l}-0.398 \\
(1.122)\end{array}$ & $\begin{array}{l}0.00155 \\
(1.123)\end{array}$ \\
\hline $\begin{array}{l}\text { Fraction of fathers with } \\
\text { complete tertiary education }\end{array}$ & $\begin{array}{l}-0.288 \\
(1.203)\end{array}$ & $\begin{array}{l}-0.118 \\
(1.227)\end{array}$ & $\begin{array}{l}0.0108 \\
(1.317)\end{array}$ & $\begin{array}{c}0.181 \\
(1.321)\end{array}$ \\
\hline $\begin{array}{l}\text { Fraction of fathers with } \\
\text { tertiary education }\end{array}$ & $\begin{array}{l}-0.111 \\
(0.962)\end{array}$ & $\begin{array}{l}0.0828 \\
(0.987)\end{array}$ & $\begin{array}{l}0.257 \\
(1.070)\end{array}$ & $\begin{array}{l}0.476 \\
(1.079)\end{array}$ \\
\hline $\begin{array}{l}\text { Fraction of mothers with } \\
\text { primary education }\end{array}$ & $\begin{array}{l}-0.253 \\
(0.929)\end{array}$ & $\begin{array}{l}-0.396 \\
(0.963)\end{array}$ & $\begin{array}{l}-0.515 \\
(1.078)\end{array}$ & $\begin{array}{l}-0.653 \\
(1.097)\end{array}$ \\
\hline $\begin{array}{l}\text { Fraction of mothers with } \\
\text { incomplete secondary education }\end{array}$ & $\begin{array}{l}-0.583 \\
(1.021)\end{array}$ & $\begin{array}{l}-0.756 \\
(1.056)\end{array}$ & $\begin{array}{l}-0.890 \\
(1.172)\end{array}$ & $\begin{array}{l}-1.078 \\
(1.190)\end{array}$ \\
\hline $\begin{array}{l}\text { Fraction of mothers with } \\
\text { complete tertiary education }\end{array}$ & $\begin{array}{l}-0.408 \\
(1.303)\end{array}$ & $\begin{array}{l}-0.661 \\
(1.295)\end{array}$ & $\begin{array}{l}-0.853 \\
(1.445)\end{array}$ & $\begin{array}{l}-1.054 \\
(1.399)\end{array}$ \\
\hline $\begin{array}{l}\text { Fraction of mothers with } \\
\text { tertiary education }\end{array}$ & $\begin{array}{l}-0.347 \\
(0.975)\end{array}$ & $\begin{array}{l}-0.400 \\
(1.013)\end{array}$ & $\begin{array}{l}-0.714 \\
(1.093)\end{array}$ & $\begin{array}{l}-0.768 \\
(1.126)\end{array}$ \\
\hline Constant & $\begin{array}{l}3.159^{* * *} \\
(0.755)\end{array}$ & $\begin{array}{l}2.730 * * \\
(1.270)\end{array}$ & $\begin{array}{c}3.791 * * * \\
(0.936)\end{array}$ & $\begin{array}{l}2.824^{*} \\
(1.601)\end{array}$ \\
\hline Previous grade retention & Yes & Yes & Yes & Yes \\
\hline $\begin{array}{l}\text { 4th and 5th grade schools } \\
\text { characteristics }\end{array}$ & Yes & Yes & Yes & Yes \\
\hline Municipal characteristics & No & Yes & No & Yes \\
\hline Observations & 956,929 & 956,929 & 83,988 & 83,988 \\
\hline
\end{tabular}

Note: Standard errors in parentheses; * Significant at the 10 percent level, ** Significant at the 5 percent level, ${ }^{* * *}$ Significant at the 1 percent level. We cluster standard errors by school attended at 4 th grade. 
Table 6: Effect of School Closure on Grade Retention (Equation (2))

\begin{tabular}{|c|c|c|c|c|c|c|}
\hline & \multicolumn{3}{|c|}{ All Students } & \multicolumn{3}{|c|}{ Students Switching Schools } \\
\hline & Probit & Biprobit (1) & Biprobit (2) & Probit & Biprobit (1) & Biprobit (2) \\
\hline School closure & $\begin{array}{l}0.221^{* *} \\
(0.0888)\end{array}$ & $\begin{array}{l}0.381^{*} \\
(0.228)\end{array}$ & $\begin{array}{l}0.427^{*} \\
(0.227)\end{array}$ & $\begin{array}{c}0.101 \\
(0.0798)\end{array}$ & $\begin{array}{l}0.498^{*} \\
(0.256)\end{array}$ & $\begin{array}{l}0.490^{*} \\
(0.253)\end{array}$ \\
\hline Math test score & $\begin{array}{c}-0.00406 * * * \\
(0.000112)\end{array}$ & $\begin{array}{c}-0.00406 * * * \\
(0.000112)\end{array}$ & $\begin{array}{c}-0.00391 * * * \\
(0.000114)\end{array}$ & $\begin{array}{c}-0.00553^{* * *} \\
(0.000288)\end{array}$ & $\begin{array}{c}-0.00553 * * * \\
(0.000288)\end{array}$ & $\begin{array}{c}-0.00541^{* * *} \\
(0.000289)\end{array}$ \\
\hline Language test score & $\begin{array}{c}-0.00247^{* * *} \\
(9.75 \mathrm{e}-05)\end{array}$ & $\begin{array}{c}-0.00247^{* * *} \\
(9.75 \mathrm{e}-05)\end{array}$ & $\begin{array}{c}-0.00262 * * * \\
(9.72 \mathrm{e}-05)\end{array}$ & $\begin{array}{c}-0.00293^{* * *} \\
(0.000262)\end{array}$ & $\begin{array}{c}-0.00292 * * * \\
(0.000262)\end{array}$ & $\begin{array}{c}-0.00306^{* * *} \\
(0.000262)\end{array}$ \\
\hline GPA at 4 th grade & $\begin{array}{c}-1.055^{* * *} \\
(0.0175)\end{array}$ & $\begin{array}{c}-1.055^{* * *} \\
(0.0175)\end{array}$ & $\begin{array}{c}-1.060^{* * *} \\
(0.0179)\end{array}$ & $\begin{array}{c}-0.600 * * * \\
(0.0232)\end{array}$ & $\begin{array}{c}-0.599 * * * \\
(0.0232)\end{array}$ & $\begin{array}{c}-0.604 * * * \\
(0.0233)\end{array}$ \\
\hline Attendance at 4 th grade & $\begin{array}{l}0.000895 \\
(0.00124)\end{array}$ & $\begin{array}{l}0.000892 \\
(0.00124)\end{array}$ & $\begin{array}{c}0.00115 \\
(0.00127)\end{array}$ & $\begin{array}{c}0.00728^{* * *} \\
(0.00168)\end{array}$ & $\begin{array}{c}0.00724^{* * *} \\
(0.00168)\end{array}$ & $\begin{array}{c}0.00760 * * * \\
(0.00169)\end{array}$ \\
\hline Female & $\begin{array}{r}-0.216^{* * *} \\
(0.00793)\end{array}$ & $\begin{array}{r}-0.216^{* * *} \\
(0.00793)\end{array}$ & $\begin{array}{l}-0.212^{* * *} \\
(0.00793)\end{array}$ & $\begin{array}{c}-0.260^{* * *} \\
(0.0198)\end{array}$ & $\begin{array}{c}-0.260^{* * *} \\
(0.0198)\end{array}$ & $\begin{array}{c}-0.257^{* * *} \\
(0.0198)\end{array}$ \\
\hline Enrollment in 2005 & $\begin{array}{l}-8.95 \mathrm{e}-06 \\
(1.49 \mathrm{e}-05)\end{array}$ & $\begin{array}{l}-8.71 \mathrm{e}-06 \\
(1.49 \mathrm{e}-05)\end{array}$ & $\begin{array}{l}-3.88 \mathrm{e}-06 \\
(1.57 \mathrm{e}-05)\end{array}$ & $\begin{array}{l}-6.00 \mathrm{e}-05^{* * *} \\
(2.31 \mathrm{e}-05)\end{array}$ & $\begin{array}{c}-5.37 \mathrm{e}-05^{* *} \\
(2.26 \mathrm{e}-05)\end{array}$ & $\begin{array}{c}-4.99 \mathrm{e}-05^{* *} \\
(2.24 \mathrm{e}-05)\end{array}$ \\
\hline $\begin{array}{l}\text { Mother with primary } \\
\text { education }\end{array}$ & $\begin{array}{c}-0.0617^{* * *} \\
(0.0108)\end{array}$ & $\begin{array}{l}-0.0617^{* * *} * \\
\quad(0.0108)\end{array}$ & $\begin{array}{c}-0.0614^{* * *} \\
(0.0109)\end{array}$ & $\begin{array}{c}-0.0809 * * \\
(0.0340)\end{array}$ & $\begin{array}{c}-0.0809^{* *} \\
(0.0340)\end{array}$ & $\begin{array}{c}-0.0807^{* *} \\
(0.0341)\end{array}$ \\
\hline $\begin{array}{l}\text { Mother with incomplete } \\
\text { secondary education }\end{array}$ & $\begin{array}{c}-0.0694^{* * *} \\
(0.0110)\end{array}$ & $\begin{array}{l}-0.0694^{* * *} \\
(0.0110)\end{array}$ & $\begin{array}{l}-0.0684^{* * *} \\
(0.0110)\end{array}$ & $\begin{array}{l}-0.0614^{*} \\
(0.0328)\end{array}$ & $\begin{array}{l}-0.0616^{*} \\
(0.0328)\end{array}$ & $\begin{array}{l}-0.0613^{*} \\
(0.0328)\end{array}$ \\
\hline $\begin{array}{l}\text { Mother with complete } \\
\text { tertiary education }\end{array}$ & $\begin{array}{c}-0.171 * * * \\
(0.0111)\end{array}$ & $\begin{array}{c}-0.171 * * * \\
(0.0111)\end{array}$ & $\begin{array}{c}-0.171 * * * \\
(0.0112)\end{array}$ & $\begin{array}{c}-0.213^{* * *} \\
(0.0338)\end{array}$ & $\begin{array}{c}-0.213^{* * *} \\
(0.0338)\end{array}$ & $\begin{array}{c}-0.215^{* * *} \\
(0.0338)\end{array}$ \\
\hline $\begin{array}{l}\text { Mother with tertiary } \\
\text { education }\end{array}$ & $\begin{array}{c}-0.220 * * * \\
(0.0144)\end{array}$ & $\begin{array}{c}-0.220 * * * \\
(0.0144)\end{array}$ & $\begin{array}{c}-0.218^{* * *} \\
(0.0145)\end{array}$ & $\begin{array}{c}-0.236 * * * \\
(0.0404)\end{array}$ & $\begin{array}{c}-0.236 * * * \\
(0.0403)\end{array}$ & $\begin{array}{c}-0.237^{* * *} \\
(0.0404)\end{array}$ \\
\hline $\begin{array}{l}\text { Father with primary } \\
\text { education }\end{array}$ & $\begin{array}{r}-0.0203^{*} \\
(0.0111)\end{array}$ & $\begin{array}{r}-0.0203^{*} \\
(0.0111)\end{array}$ & $\begin{array}{l}-0.0217^{*} \\
(0.0112)\end{array}$ & $\begin{array}{l}-0.0267 \\
(0.0357)\end{array}$ & $\begin{array}{l}-0.0262 \\
(0.0357)\end{array}$ & $\begin{array}{l}-0.0275 \\
(0.0356)\end{array}$ \\
\hline $\begin{array}{l}\text { Father with incomplete } \\
\text { secondary education }\end{array}$ & $\begin{array}{c}-0.0231^{* *} \\
(0.0108)\end{array}$ & $\begin{array}{c}-0.0231 * * \\
(0.0108)\end{array}$ & $\begin{array}{c}-0.0233^{* *} \\
(0.0108)\end{array}$ & $\begin{array}{r}-0.00721 \\
(0.0345)\end{array}$ & $\begin{array}{r}-0.00693 \\
(0.0344)\end{array}$ & $\begin{array}{r}-0.00738 \\
(0.0345)\end{array}$ \\
\hline $\begin{array}{l}\text { Father with complete } \\
\text { secondary education }\end{array}$ & $\begin{array}{c}-0.0719^{* * *} \\
(0.0110)\end{array}$ & $\begin{array}{c}-0.0719^{* * *} \\
(0.0110)\end{array}$ & $\begin{array}{c}-0.0726^{* * *} \\
(0.0110)\end{array}$ & $\begin{array}{l}-0.0601 * \\
(0.0339)\end{array}$ & $\begin{array}{r}-0.0596^{*} \\
(0.0339)\end{array}$ & $\begin{array}{r}-0.0602^{*} \\
(0.0339)\end{array}$ \\
\hline $\begin{array}{l}\text { Father with tertiary } \\
\text { education }\end{array}$ & $\begin{array}{c}-0.0846^{* * *} \\
(0.0143)\end{array}$ & $\begin{array}{c}-0.0846 * * * \\
(0.0143)\end{array}$ & $\begin{array}{c}-0.0849 * * * \\
(0.0143)\end{array}$ & $\begin{array}{l}-0.0596 \\
(0.0405)\end{array}$ & $\begin{array}{l}-0.0592 \\
(0.0405)\end{array}$ & $\begin{array}{l}-0.0591 \\
(0.0405)\end{array}$ \\
\hline Constant & $\begin{array}{c}4.073^{* * *} \\
(0.237)\end{array}$ & $\begin{array}{c}4.067^{* * *} \\
(0.237)\end{array}$ & $\begin{array}{l}4.516^{* * *} \\
(0.295)\end{array}$ & $\begin{array}{l}1.014^{* *} \\
(0.405)\end{array}$ & $\begin{array}{c}0.886^{* *} \\
(0.414)\end{array}$ & $\begin{array}{c}1.223^{* * *} \\
(0.462)\end{array}$ \\
\hline $\operatorname{Corr}(u, v)$ & & $\begin{array}{l}-0.0561 \\
(0.0690)\end{array}$ & $\begin{array}{l}-0.0684 \\
(0.0678)\end{array}$ & & $\begin{array}{c}-0.176^{*} \\
(0.105)\end{array}$ & $\begin{array}{l}-0.170 \\
(0.104)\end{array}$ \\
\hline Previous grade retention & Yes & Yes & Yes & Yes & Yes & Yes \\
\hline $\begin{array}{l}4 \text { th and } 5 \text { th grade schools } \\
\text { characteristics }\end{array}$ & Yes & Yes & Yes & Yes & Yes & Yes \\
\hline Municipal characteristics & No & No & Yes & No & No & Yes \\
\hline Observations & 956,929 & 956,929 & 956,929 & 83,988 & 83,988 & 83,988 \\
\hline
\end{tabular}

Note: Standard errors in parentheses; ${ }^{*}$ Significant at the 10 percent level, ${ }^{* *}$ Significant at the 5 percent level, *** Significant at the 1 percent level. We cluster standard errors by school attended at 4 th grade. 


\section{Conclusions}

In 1981, Chile introduced school finance reforms creating a liberalized school market that had been in place for more than 30 years without significant changes. The creation of new schools has been weakly regulated, making it a free-entry-and-exit market. During the last two decades a massive destruction and replacement of schools was a distinctive characteristic of the market-oriented Chilean education system.

Given this significant school turnover we estimate the potential educational costs of this dynamics intending to identify the causal effect of school closure on grade repetition and high-school dropout rates. Using a large panel of individual student administrative data for the period 2002-2012, we identify a causal effect of school closures on school dropouts and grade retention. School closure increases the probability of high-school dropout between 46 and 62 percent (1.7 and 2.3 percentage points). Also, school exit implies a 78 percent increase in the probability of grade retention in fifth grade. If we only consider those students that switch school at the end of the 4th grade we find an increase between 4.8 and 4.9 percentage points in grade retention. These results are robust to different robustness check.

The results of this paper, together with recent evidence for the US on the impact of school closures on student outcomes, suggest that school closing is not necessarily effective as a policy measure to improve student achievement. Producing higher levels of achievement would require moving students to schools that perform significantly better than the closing school, in order to compensate for the adverse effects on students' attendance and achievement of a transition to a new school. This finding holds if school closure is a planned decision as it has been the case in US school districts, or if it is determined by market competition, as it has been the case in Chile. 


\section{References}

Abadie, A., D. Drukker, J. Herr, and G. Imbens (2004). Implementing matching estimators for average treatment effects in Stata. The Stata Journal, Number 3, pp. 290 ?311.

Abadie, A., and Imbens, G. (2011). Bias-Corrected Matching Estimators for Average Treatment Effects. Journal of Business and Economic Statistics, 29(1), 1-11.

Aizer, A. (2010). The Gender Wage Gap and Domestic Violence. American Economic Review, 100(4): 1847-59.

Autor, D., and M. Duggan (2003). The Rise in the Disability Rolls and the Decline in Unemployment. The Quarterly Journal of Economics, Vol. 118, No. 1, pp. 157-205.

Bartelsman, E., J. Haltiwanger, and S. Scarpetta (2004). Microeconomic Evidence of Creative Destruction in Industrial and Developing Countries, Tinbergen Institute Discussion Paper, No. 04-114/3.

Bartik, T. (1991). Who Benefits from State and Local Economic Development Policies?, Books from Upjohn Press, W.E. Upjohn Institute for Employment Research.

Blanchard, O., L. Katz, R. Hall, and B. Eichengreen (1992). Regional Evolutions. Brookings Papers on Economic Activity, Vol. 1992, No. 1, pp. 1-75.

Booker, K., S. Gilpatric, T. Gronberg, and D. Jansen (2007) The impact of charter school attendance on student performance. Journal of Public Economics, Volume 91, Issues 5-6, Pages 849-876.

Bound J. and H. Holzer (2000). Demand Shifts, Population Adjustments, and Labor Market Outcomes during the 1980s. Journal of Labor Economics, Vol. 18, No. 1, pp. 20-54. 
Card, D. (2001). Immigrant Inflows, Native Outflows, and the Local Labor Market Impacts of Higher Immigration. Journal of Labor Economics, University of Chicago Press, vol. 19(1), pages 22-64, January.

De la Torre, M., and J. Gwynne. (2009). When Schools Close: Effects on Displaced Students in Chicago Public Schools. Research Report. Consortium on Chicago School Research. University of Chicago.

Diaz, J., Grau, N., Reyes, T., and J. Rivera (2016). The effect of grade retention of youth crime. Working Paper, University of Chile.

Egelund, N. and H. Laustsen (2006) School Closure: What are the consequences for the local society?, Scandinavian Journal of Educational Research, 50:4, 429-439.

Engberg, J., Gill, B., Zamarro, G., and R. Zimmer (2012). Closing schools in a shrinking district: Do student outcomes depend on which schools are closed? Journal of Urban Economics, 71(2), 189-203.

Gauri, V. (1999). School Choice In Chile: Two Decades of Educational Reform. Pitt Latin American Studies. University of Pittsburgh Press.

Grau, N., D. Hojman, and A. Mizala (2015) Destructive Creation: School Turnover and Educational Attainment. Series de Documentos de Trabajo, 396. Universidad de Chile.

Griliches, Z. and Regev H. (1995). Productivity and Firm Turnover in Israeli Industry: 19791988. NBER Working Paper 4059.

Hanushek, E., J. Kain, and S. Rivkin (2004). Disruption versus Tiebout improvement: the costs and benefits of switching schools. Journal of Public Economics, Volume 88, 1721-1746. 
Imbens, G. (2004). Nonparametric estimation of average treatment effects under exogeneity: A review. Review of Economics and Statistics 86(1): 4?29.

Imbens, G. and J. Wooldridge, (2009). Recent Developments in the Econometrics of Program Evaluation, Journal of Economic Literature, American Economic Association, vol. 47(1), pages 5-86, March.

Jacob, B. A. and L. Lefgren (2009). The Effect of Grade Retention on High School Completion. American Economic Journal: Applied Economics 1(3), 33-58.

Kirshner, B., M. Gaertner, K. Pozzoboni (2010). Tracing Transitions The Effect of High School Closure on Displaced Students. Educational evaluation and policy analysis, 32(3), 407-429.

Lara, B., A. Mizala, and A. Repetto (2011). The Effectiveness of Private Voucher Education: Evidence from Structural School Switches. Educational Evaluation and Policy Analysis 33(2), 2011: 119-137.

Manacorda, M. (2012). The Cost of Grade Retention. The Review of Economics and Statistics 94(2), 596-606.

Ozek, U. (2009). The effects of open enrolment on school choice and student outcomes. CALDER Working Paper 26, National Center for Analysis of Longitudinal Data in Education Research.

Rubin, D. (1974). "Estimating Causal Effects of Treatments in Randomized and Nonrandomized Studies". Journal of Educational Psychology 66 (5): 688?701.

Schumpeter, J. (2014). [1942]. Capitalism, socialism and democracy (2nd ed.). Floyd, Virginia: Impact Books. 
Witten, K., T. McCreanor, R. Kearns, and L. Ramasubramanian (2001). The impacts of school closure on neighbourhood social cohesion: narratives from Invercargill, New Zealand. Health \& Place 7, 307-317.

Wooldridge, J. (2002). Econometric Analysis of Cross Section and Panel Data. Cambridge, MA: MIT Press.

Xu, Z., J. Hannaway, and S. D'souza (2009). Student transience in North Carolina: The effect of school mobility on student outcomes using longitudinal data. Presentation for the Workshop on the Impact of Mobility and Change on the Lives of Young Children, Schools, and Neighborhoods, June 29?30, The National Academies, Washington, DC.

Young. V.M., D.C. Humphrey, H. Wang, K.R. Bosetti, L. Cassidy, M.E. Wechsler, E. Rivera, S. Murray, D.W. Schanzenbach (2009). Renaissance Schools Fund-Supported Schools: Early outcomes, challenges and opportunities. SRI, International, Merlo Park, CA. 


\section{Appendix A Dropout: Robustness check}

In this appendix, we present the results of a simpler empirical strategy. For some years and cohorts we can use information from the SIMCE standardized test database. Specifically, we have tenth grade standardized test scores at the individual level for some cohorts. We compare the dropout rates in tenth grade and thereafter, for students whose school closed in tenth grade to the rates of those whose school did not close that year-grade. We use all the years for which we have standardized test information and student individual data, namely, 2003, 2006, and 2008. ${ }^{20}$ Thus, in contrast to the strategy presented in the maintext, we do not compare students of different cohorts who attend schools that close at some point. We pay the cost of loosing an important fraction of our data set and focus on the students for whom we have test score information. ${ }^{21}$

The effect of school closure is estimated with the following probit model:

$$
\operatorname{Pr}\left(\operatorname{Drop}_{i k t}=1\right)=\Phi\left(\beta_{0}+\beta_{1} W_{i t-1}+\beta_{2} X_{i t-1}+\beta_{3} H_{i}+\beta_{4} S_{k}+\eta_{t}\right)
$$

where $\operatorname{Drop}_{i k t}$ takes a value one if individual $i$, who attended school $k$ at 10 th grade, leaves the educational system at time $t$ when he/she was attending tenth grade and zero, otherwise. As before, $W$ stands for a school closure dummy; $X$ includes language test score and math test score, GPA, and attendance rate; $H$ includes gender, dummies for parents' education; and $S_{k}$ includes a set of school $k$ characteristics such as the type of administration, the school mean in math and language test scores and the school dropout rate at $t-1 ;{ }^{22} \eta$ is a time fixed effect.

\footnotetext{
${ }^{20}$ We do not include the year 2010 in the main specification because one of our specifications would require data on school exits in 2013, which is not available.

${ }^{21}$ Thus, we miss all the cohorts that did not take the tests and the students who did not attend the day the test was administered.

${ }^{22}$ Given data restrictions (we only have student individual data since 2002), to avoid using the same cohort twice, to calculate the school dropout rate in $t-1$, we define a dropout as a student who is missing for at least one year from the official students registry of the MoE.
} 
Table 7: Effect of School Closure on Student Dropouts (Probit MARginal EFFECTS)

\begin{tabular}{|c|c|c|c|}
\hline & $(1)$ & $(2)$ & (3) \\
\hline School closure & $\begin{array}{l}0.0146^{* * *} \\
(0.00492)\end{array}$ & $\begin{array}{l}0.0143^{* * *} \\
(0.00478)\end{array}$ & $\begin{array}{l}0.0044^{*} \\
(0.00305)\end{array}$ \\
\hline Language test score & $\begin{array}{r}-0.0000 * * * \\
(0.00000)\end{array}$ & $\begin{array}{c}-0.0000^{* * *} \\
(0.00000)\end{array}$ & $\begin{array}{c}-0.0000^{* * *} \\
(0.00000)\end{array}$ \\
\hline Math test score & $\begin{array}{c}-0.0000^{* * *} \\
(0.00000)\end{array}$ & $\begin{array}{c}-0.0000^{* * *} \\
(0.00000)\end{array}$ & $\begin{array}{c}-0.0000^{* * *} \\
(0.00000)\end{array}$ \\
\hline GPA at 12 th grade & $\begin{array}{r}-0.0078 * * * \\
(0.00033)\end{array}$ & $\begin{array}{c}-0.0070^{* * *} \\
(0.00032)\end{array}$ & $\begin{array}{c}-0.0067^{* * *} \\
(0.00025)\end{array}$ \\
\hline Attendance at 12 th grade & $\begin{array}{l}-0.0002^{* * *} \\
0.00002)\end{array}$ & $\begin{array}{c}-0.0002^{* * *} \\
(0.00002)\end{array}$ & $\begin{array}{c}-0.0001 * * * \\
(0.00001)\end{array}$ \\
\hline Female & $\begin{array}{l}0.0009^{* * *} \\
(0.00029)\end{array}$ & $\begin{array}{l}0.0008^{* * * *} \\
(0.00028)\end{array}$ & $\begin{array}{l}0.0011 * * * \\
(0.00023)\end{array}$ \\
\hline \multicolumn{4}{|l|}{ Education of parents } \\
\hline Mother with primary education & & $\begin{array}{r}-0.0018^{* * *} \\
(0.00025)\end{array}$ & $\begin{array}{r}-0.0016^{* * *} \\
(0.00025)\end{array}$ \\
\hline $\begin{array}{l}\text { Mother with incomplete secondary } \\
\text { education }\end{array}$ & & $\begin{array}{r}-0.0026^{* * *} \\
(0.00025)\end{array}$ & $\begin{array}{c}-0.0021 * * * \\
(0.00024)\end{array}$ \\
\hline $\begin{array}{l}\text { Mother with complete secondary } \\
\text { education }\end{array}$ & & $\begin{array}{c}-0.0040^{* * *} \\
(0.00026)\end{array}$ & $\begin{array}{c}-0.0030^{* * *} \\
(0.00026)\end{array}$ \\
\hline Mother with tertiary education & & $\begin{array}{c}-0.0016^{* * *} \\
(0.00030)\end{array}$ & $\begin{array}{c}-0.0008^{* * *} \\
(0.00031)\end{array}$ \\
\hline Father with primary education & & $\begin{array}{c}-0.0014 * * * \\
(0.00027)\end{array}$ & $\begin{array}{c}-0.0012^{* * *} \\
(0.00025)\end{array}$ \\
\hline $\begin{array}{l}\text { Father with incomplete secondary } \\
\text { education }\end{array}$ & & $\begin{array}{c}-0.0023^{* * *} \\
(0.00026)\end{array}$ & $\begin{array}{c}-0.0021 * * * \\
(0.00025)\end{array}$ \\
\hline $\begin{array}{l}\text { Father with complete secondary } \\
\text { education }\end{array}$ & & $\begin{array}{c}-0.0036^{* * *} \\
(0.00027)\end{array}$ & $\begin{array}{c}-0.0030^{* * *} \\
(0.00026)\end{array}$ \\
\hline Father with tertiary education & & $\begin{array}{r}-0.0011^{* * *} \\
(0.00030)\end{array}$ & $\begin{array}{c}-0.0009 * * * \\
(0.00029)\end{array}$ \\
\hline \multicolumn{4}{|l|}{ School Characteristics } \\
\hline Voucher-private School & & & $\begin{array}{l}0.0002 \\
(0.00029)\end{array}$ \\
\hline Non Voucher-private School & & & $\begin{array}{l}0.0059^{* * *} \\
(0.00125)\end{array}$ \\
\hline $\begin{array}{l}\text { School Mean Score in } \\
\text { Math test }\end{array}$ & & & $\begin{array}{c}-0.00003^{* * *} \\
(0.000013)\end{array}$ \\
\hline $\begin{array}{l}\text { School Mean Score in } \\
\text { Language test }\end{array}$ & & & $\begin{array}{l}-0.00001 \\
(0.000022)\end{array}$ \\
\hline School Dropout rate at $t-1$ & & & $\begin{array}{l}0.0365 * * * \\
(0.00533)\end{array}$ \\
\hline $\mathrm{N}$ & 682217 & 617476 & 585932 \\
\hline Pseudo R2 & 0.129 & 0.138 & 0.153 \\
\hline
\end{tabular}

Note: Standard errors in parentheses; * Significant at the 10 percent level, ** Significant at the 5 percent level, *** Significant at the 1 percent level. All models include dummies for years 2003, 2006, and 2008. We cluster standard errors by school. Given data restrictions (we only have student individual data since 2002), and to avoid using the same cohort twice, to calculate the school dropout rate in $t-1$, we define a dropout as a student who is missing for at least one year from the official students registry of the MoE.

Columns (1), (2), and (3) of Table 7 show the results of this probit regression including different sets of controls. When we include all the regressors, the effect of school closure on student dropout is a statistically significant increase of 0.44 percentage points. Since in this 
sample the dropout rate is around 1.4 percent per year, our estimate implies that school closure increases the probability of dropping out by 31 percent. 


\section{Appendix B Grade Retention}

Table 8: Marginal effect of School Closure on grade Retention (Equation (2))

\begin{tabular}{|c|c|c|c|c|}
\hline & \multicolumn{2}{|c|}{ All students } & \multicolumn{2}{|c|}{ Students Switching Schools } \\
\hline & Biprobit (1) & Biprobit (2) & Biprobit (1) & Biprobit (2) \\
\hline School closure & $\begin{array}{c}0.0247 \\
(0.0187)\end{array}$ & $\begin{array}{c}0.0285 \\
(0.0196)\end{array}$ & $\begin{array}{c}0.0492 \\
(0.0333)\end{array}$ & $\begin{array}{c}0.0481 \\
(0.0325)\end{array}$ \\
\hline Math test score & $\begin{array}{l}-0.000201 * * * \\
\quad(5.75 \mathrm{e}-06)\end{array}$ & $\begin{array}{l}-0.000193^{* * *} \\
(5.80 \mathrm{e}-06)\end{array}$ & $\begin{array}{c}-0.000396 * * * \\
(2.12 \mathrm{e}-05)\end{array}$ & $\begin{array}{c}-0.000387^{* * *} \\
(2.12 \mathrm{e}-05)\end{array}$ \\
\hline Language test score & $\begin{array}{l}-0.000122^{* * *} \\
(4.93 \mathrm{e}-06)\end{array}$ & $\begin{array}{c}-0.000130 * * * \\
(4.92 \mathrm{e}-06)\end{array}$ & $\begin{array}{l}-0.000210 * * * \\
(1.90 \mathrm{e}-05)\end{array}$ & $\begin{array}{c}-0.000219 * * * \\
(1.90 \mathrm{e}-05)\end{array}$ \\
\hline GPA at 4 th grade & $\begin{array}{c}-0.0522 * * * \\
(0.000951)\end{array}$ & $\begin{array}{r}-0.0523 * * * \\
(0.000965)\end{array}$ & $\begin{array}{c}-0.0429^{* * *} * \\
(0.00174)\end{array}$ & $\begin{array}{c}-0.0432^{* * *} \\
(0.00174)\end{array}$ \\
\hline Attendance at 4 th grade & $\begin{array}{l}4.41 \mathrm{e}-05 \\
(6.13 \mathrm{e}-05)\end{array}$ & $\begin{array}{l}5.67 \mathrm{e}-05 \\
(6.28 \mathrm{e}-05)\end{array}$ & $\begin{array}{c}0.000519 * * * \\
(0.000121)\end{array}$ & $\begin{array}{c}0.000544^{* * *} \\
(0.000121)\end{array}$ \\
\hline Female & $\begin{array}{c}-0.0107^{* * *} * \\
(0.000396)\end{array}$ & $\begin{array}{r}-0.0105 * * * \\
(0.000396)\end{array}$ & $\begin{array}{c}-0.0187^{* * *} * \\
(0.00144)\end{array}$ & $\begin{array}{c}-0.0184^{* * *} \\
(0.00143)\end{array}$ \\
\hline Enrollment in 2005 & $\begin{array}{l}-4.31 \mathrm{e}-07 \\
(7.37 \mathrm{e}-07)\end{array}$ & $\begin{array}{l}-1.91 \mathrm{e}-07 \\
(7.73 \mathrm{e}-07)\end{array}$ & $\begin{array}{c}-3.85 \mathrm{e}-06^{* *} \\
(1.62 \mathrm{e}-06)\end{array}$ & $\begin{array}{c}-3.57 \mathrm{e}-06^{* *} \\
(1.60 \mathrm{e}-06)\end{array}$ \\
\hline $\begin{array}{l}\text { Mother with primary } \\
\text { education }\end{array}$ & $\begin{array}{c}-0.00344^{* * *} * \\
(0.000604)\end{array}$ & $\begin{array}{c}-0.00341 * * * \\
(0.000605)\end{array}$ & $\begin{array}{c}-0.00668^{* * *} \\
(0.00281)\end{array}$ & $\begin{array}{c}-0.00665^{* *} \\
(0.00282)\end{array}$ \\
\hline $\begin{array}{l}\text { Mother with incomplete } \\
\text { secondary education }\end{array}$ & $\begin{array}{c}-0.00385^{* * *} \\
(0.000616)\end{array}$ & $\begin{array}{c}-0.00378^{* * *} * \\
(0.000615)\end{array}$ & $\begin{array}{l}-0.00515^{*} \\
(0.00277)\end{array}$ & $\begin{array}{r}-0.00511^{*} \\
(0.00277)\end{array}$ \\
\hline $\begin{array}{l}\text { Mother with complete } \\
\text { tertiary education }\end{array}$ & $\begin{array}{c}-0.00883^{* * *} * \\
(0.000603)\end{array}$ & $\begin{array}{c}-0.00880 * * * \\
(0.000602)\end{array}$ & $\begin{array}{c}-0.0161^{* * *} \\
(0.00272)\end{array}$ & $\begin{array}{c}-0.0162^{* * *} \\
(0.00272)\end{array}$ \\
\hline $\begin{array}{l}\text { Mother with tertiary } \\
\text { education }\end{array}$ & $\begin{array}{c}-0.0109^{* * *} \\
(0.000726)\end{array}$ & $\begin{array}{r}-0.0109^{* * *} * \\
(0.000726)\end{array}$ & $\begin{array}{c}-0.0175^{* * * *} \\
(0.00308)\end{array}$ & $\begin{array}{c}-0.0176^{* * *} \\
(0.00307)\end{array}$ \\
\hline $\begin{array}{l}\text { Father with primary } \\
\text { education }\end{array}$ & $\begin{array}{l}-0.00105^{*} \\
(0.000580)\end{array}$ & $\begin{array}{l}-0.00113^{*} \\
(0.000580)\end{array}$ & $\begin{array}{l}-0.00195 \\
(0.00265)\end{array}$ & $\begin{array}{l}-0.00203 \\
(0.00264)\end{array}$ \\
\hline $\begin{array}{l}\text { Father with incomplete } \\
\text { secondary education }\end{array}$ & $\begin{array}{r}-0.00120 * * \\
(0.000563)\end{array}$ & $\begin{array}{r}-0.00121 * * \\
(0.000563)\end{array}$ & $\begin{array}{r}-0.000521 \\
(0.00259)\end{array}$ & $\begin{array}{r}-0.000553 \\
(0.00259)\end{array}$ \\
\hline $\begin{array}{l}\text { Father with complete } \\
\text { secondary education }\end{array}$ & $\begin{array}{c}-0.00360 * * * \\
(0.000561)\end{array}$ & $\begin{array}{c}-0.00363^{* * *} \\
(0.000560)\end{array}$ & $\begin{array}{r}-0.00432 * \\
(0.00251)\end{array}$ & $\begin{array}{r}-0.00436^{*} \\
(0.00250)\end{array}$ \\
\hline $\begin{array}{l}\text { Father with tertiary } \\
\text { education }\end{array}$ & $\begin{array}{c}-0.00420 * * * \\
(0.000708)\end{array}$ & $\begin{array}{c}-0.00421^{* * *} \\
(0.000708)\end{array}$ & $\begin{array}{l}-0.00429 \\
(0.00296)\end{array}$ & $\begin{array}{l}-0.00428 \\
(0.00295)\end{array}$ \\
\hline Previous grade retention & Yes & Yes & Yes & Yes \\
\hline $\begin{array}{l}4 \text { th and } 5 \text { th grade schools } \\
\text { characteristics }\end{array}$ & Yes & Yes & Yes & Yes \\
\hline Municipal characteristics & No & Yes & No & Yes \\
\hline Observations & 956,929 & 956,929 & 83,988 & 83,988 \\
\hline
\end{tabular}

Note: All parameters represent the marginal effects. Standard errors in parentheses; * Significant at the 10 percent level, ** Significant at the 5 percent level. *** Significant at the 1 percent level. We cluster standard errors by school attended at 4th grade. 


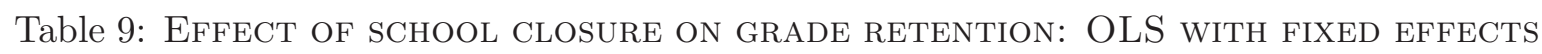

\begin{tabular}{|c|c|c|c|c|c|c|}
\hline & \multicolumn{3}{|c|}{ All Students } & \multicolumn{3}{|c|}{ Students Switching Schools } \\
\hline & $(1)$ & $(2)$ & $(3)$ & $(4)$ & $(5)$ & $(6)$ \\
\hline School exit & $\begin{array}{l}0.0446^{* * *} \\
(0.00929)\end{array}$ & $\begin{array}{l}0.0302 * * * \\
(0.00920)\end{array}$ & $\begin{array}{l}0.0248^{* * *} \\
(0.00926)\end{array}$ & $\begin{array}{l}0.0281^{* * * *} \\
(0.00902)\end{array}$ & $\begin{array}{c}0.0173^{*} \\
(0.00896)\end{array}$ & $\begin{array}{l}0.0135 \\
(0.0091)\end{array}$ \\
\hline Math test score & $\begin{array}{c}-0.0001 * * * \\
(0.000006)\end{array}$ & $\begin{array}{r}-0.0001 * * * \\
(0.000006)\end{array}$ & $\begin{array}{r}-0.0001^{* * * *} \\
(0.000006)\end{array}$ & $\begin{array}{c}-0.0004 * * * \\
(0.00002)\end{array}$ & $\begin{array}{r}-0.0003^{* * *} * \\
(0.00002)\end{array}$ & $\begin{array}{c}-0.0003^{* * *} \\
(0.000022)\end{array}$ \\
\hline Language test score & $\begin{array}{r}-0.0001^{* * *} \\
(0.000006)\end{array}$ & $\begin{array}{r}-0.0001^{* * *} \\
(0.000006)\end{array}$ & $\begin{array}{c}-0.0001^{* * *} \\
(0.00009)\end{array}$ & $\begin{array}{c}-0.0003^{* * *} \\
(0.00002)\end{array}$ & $\begin{array}{c}-0.0002^{* * *} \\
(0.00002)\end{array}$ & $\begin{array}{c}-0.0002^{* * *} \\
(0.000021)\end{array}$ \\
\hline GPA at 4 th grade & $\begin{array}{c}-0.0620 * * * \\
(0.00086)\end{array}$ & $\begin{array}{r}-0.0584 * * * \\
(0.00084)\end{array}$ & $\begin{array}{r}-0.0571 * * * \\
(0.01648)\end{array}$ & $\begin{array}{c}-0.0508^{* * *} \\
(0.0019)\end{array}$ & $\begin{array}{c}-0.0507 * * * \\
(0.00208)\end{array}$ & $\begin{array}{c}-0.0490^{* * *} \\
(0.0019)\end{array}$ \\
\hline Attendance at 4 th grade & $\begin{array}{c}-0.0006^{* * *} \\
(0.00006)\end{array}$ & $\begin{array}{c}-0.0004^{* * *} \\
(0.00005)\end{array}$ & $\begin{array}{l}-0.003^{* * *} \\
(0.00118)\end{array}$ & $\begin{array}{l}-0.0000 \\
(0.00014)\end{array}$ & $\begin{array}{c}0.00001 \\
(0.00014)\end{array}$ & $\begin{array}{l}0.0076 * * * \\
(0.00014)\end{array}$ \\
\hline Female & $\begin{array}{c}-0.0117^{* * *} \\
(0.00040)\end{array}$ & $\begin{array}{r}-0.0104 * * * \\
(0.00038)\end{array}$ & $\begin{array}{r}-0.0099^{* * *} \\
(0.00756)\end{array}$ & $\begin{array}{c}-0.0193 * * * \\
(0.0015)\end{array}$ & $\begin{array}{r}-0.0174^{* * *} \\
(0.00154)\end{array}$ & $\begin{array}{r}-0.0173 * * * \\
(0.00144)\end{array}$ \\
\hline Class size & $\begin{array}{c}-0.00001 * * * \\
(0.000001)\end{array}$ & $\begin{array}{c}-0.000005^{* * *} \\
(0.000001)\end{array}$ & $\begin{array}{c}-0.0000004 \\
(0.0000008)\end{array}$ & $\begin{array}{c}-0.00009^{* * *} \\
(0.000001)\end{array}$ & $\begin{array}{c}-0.000003^{* * *} \\
(0.000001)\end{array}$ & $\begin{array}{c}-0.000003^{* * *} \\
(0.000001)\end{array}$ \\
\hline \multicolumn{7}{|l|}{ Mother's education: } \\
\hline Mother with primary education & & $\begin{array}{r}-0.0055^{* * *} * \\
(0.00086)\end{array}$ & $\begin{array}{c}-0.0056^{* * *} * \\
(0.00086)\end{array}$ & & $\begin{array}{c}-0.0115^{* * *} * \\
(0.00405)\end{array}$ & $\begin{array}{c}-0.0120 * * * \\
(0.0039)\end{array}$ \\
\hline $\begin{array}{l}\text { Mother with incomplete secondary } \\
\text { education }\end{array}$ & & $\begin{array}{r}-0.0063^{* * *} \\
(0.00087)\end{array}$ & $\begin{array}{c}-0.0064^{* * *} \\
(0.00086)\end{array}$ & & $\begin{array}{r}-0.0097^{* *} \\
(0.00387)\end{array}$ & $\begin{array}{c}-0.0102^{* * *} \\
(0.0037)\end{array}$ \\
\hline $\begin{array}{l}\text { Mother with complete secondary } \\
\text { education }\end{array}$ & & $\begin{array}{r}-0.0104 * * * \\
(0.00079)\end{array}$ & $\begin{array}{r}-0.0106 * * * \\
(0.00079)\end{array}$ & & $\begin{array}{r}-0.0224 * * * \\
(0.00368)\end{array}$ & $\begin{array}{c}-0.0219^{* * *} \\
(0.0035)\end{array}$ \\
\hline Mother with tertiary education & & $\begin{array}{r}-0.0111^{* * *} \\
(0.00085)\end{array}$ & $\begin{array}{c}-0.0112^{* * *} \\
(.00085)\end{array}$ & & $\begin{array}{c}-0.0232 * * * \\
(0.00383)\end{array}$ & $\begin{array}{c}-0.0219^{* * *} \\
(0.0036)\end{array}$ \\
\hline \multicolumn{7}{|l|}{ Father's education: } \\
\hline Father with primary education & & $\begin{array}{r}-0.0022 * * * \\
(0.00083)\end{array}$ & $\begin{array}{r}-0.0023 * * * \\
(0.00083)\end{array}$ & & $\begin{array}{l}-0.0038 \\
(0.00399)\end{array}$ & $\begin{array}{l}-0.0054 \\
(0.0038)\end{array}$ \\
\hline $\begin{array}{l}\text { Father with incomplete secondary } \\
\text { education }\end{array}$ & & $\begin{array}{c}-0.0028 * * * \\
(0.00081)\end{array}$ & $\begin{array}{c}-0.0028^{* * *} * \\
(0.00081)\end{array}$ & & $\begin{array}{l}-0.0031 \\
(0.00380)\end{array}$ & $\begin{array}{c}-0.0029 \\
(0.0037)\end{array}$ \\
\hline $\begin{array}{l}\text { Father with complete secondary } \\
\text { education }\end{array}$ & & $\begin{array}{r}-0.0050 * * * \\
(0.00075)\end{array}$ & $\begin{array}{c}-0.0051 * * * \\
(0.00075)\end{array}$ & & $\begin{array}{l}-0.0057 \\
(0.00351)\end{array}$ & $\begin{array}{l}-0.0066^{*} \\
(0.0034)\end{array}$ \\
\hline Father with tertiary education & & $\begin{array}{r}-0.0043 * * * \\
(0.00082)\end{array}$ & $\begin{array}{r}-0.0041 * * * \\
(0.00082)\end{array}$ & & $\begin{array}{l}-0.0031 \\
(0.00376)\end{array}$ & $\begin{array}{c}-0.0043 \\
(0.0036)\end{array}$ \\
\hline Previous grade retention & NO & YES & YES & NO & YES & YES \\
\hline 4th grade school characteristics & NO & YES & YES & NO & YES & YES \\
\hline 5th grade school characteristics & NO & NO & YES & NO & $\mathrm{NO}$ & YES \\
\hline School fixed effects ( 4 th grade) & YES & YES & $\mathrm{NO}$ & YES & YES & $\mathrm{NO}$ \\
\hline $\begin{array}{l}\mathrm{N} \\
\text { adjusted } \mathrm{R} \text {-squared }\end{array}$ & $\begin{array}{c}1,043,007 \\
0.080\end{array}$ & $\begin{array}{c}956,929 \\
0.082\end{array}$ & $\begin{array}{c}956,929 \\
0.068\end{array}$ & $\begin{array}{c}92,128 \\
0.099\end{array}$ & $\begin{array}{c}83,988 \\
0.105\end{array}$ & $\begin{array}{c}83,988 \\
0.075\end{array}$ \\
\hline
\end{tabular}

Note: Standard errors in parentheses; * Significant at the 10 percent level, ** Significant at the 5 percent level, and *** Significant at the 1 percent level. We cluster standard errors by school attended at 4 th grade. 